\title{
„Dobre” społeczeństwo i państwo prawa Prolegomena do konstytucji
}

\author{
DOI: $10.35757 /$ CIV.2007.10.02
}

Jeśli chce się rozważyć zagadnienie konstytucji - „starej” czy „nowej” - jako naczelnego prawa państwa, trzeba zaczać od przemyślenia spraw podstawowych. Oznacza to, że wszelka analizę i ocenę ustawy zasadniczej, namysł nad jej preambuła, rozdziałami i ich kolejnością, paragrafami, szczegółową zawartością i konkretnymi rozwiązaniami ustrojowymi oraz logiką całości, wszelkie zatem projektowanie konstytucji, należy poprzedzić rozważaniami jak najbardziej ogólnymi, dotyczącymi samego pojęcia państwa konstytucyjnego, a ściślej - rozważaniami dotyczącymi specyficznej odmiany państwa konstytucyjnego, jakim jest państwo prawa. Moga one być prowadzone bardzo rozmaicie i dotyczyć wielu różnych kwestii. Państwo prawa ma długa tradycję, rozmaite upostaciowania, uzasadnienia, pojawia się w różnych kontekstach teoretycznych, nie tylko jako liberalne lub socjalne, formalne czy materialne państwo prawa.

W tym miejscu chcę podjąć rozważania, które będą skoncentrowane na pewnym szczególnym problemie związanym $z$ pojęciem państwa prawa; pragnę je podjąć ze względu na istotne znaczenie, jakie mu przypisuję, a także $z$ racji znamiennego faktu, że prob-

Pawet Kaczorowski - doktor habilitowany, pracuje na Uniwersytecie Kardynała Stefana Wyszyńskiego w Warszawie oraz w Instytucie Studiów Politycznych Polskiej Akademii Nauk. Redaktor naczelny „Civitas”. 
lem ten prawie w ogóle nie jest podejmowany, nie jest omawiany, ale wręcz pomijany. Jest to zdumiewające, jeśli wziąć pod uwage jego znaczenie; można byłoby nawet powiedzieć, że dla koncepcji państwa prawa charakterystyczne jest to, że problem ten przemilcza, odsuwa.

Chodzi mi mianowicie o kwestię społecznych podstaw lub, inaczej mówiąc, przedpolitycznych założeń państwa prawa, kwestię społecznych warunków możliwości państwa prawa. Pytanie, w największym skrócie, brzmi następująco: jakie jest społeczeństwo, w którym ma funkcjonować państwo prawa, jaka jest kondycja moralna tego społeczeństwa. Dodam od razu, że rozważania prowadzone na kanwie tego właśnie pytania maja charakter wstępny i chodzi w nich tylko o wskazanie problemu i kilku konsekwencji z nim związanych, a nie o jego pełne, choćby i ogólne, omówienie ${ }^{1}$.

Idea państwa prawa, demokratycznego państwa prawa, została zapisana w artykule 1 rozdziału II Konstytucji RP z roku 1997. Stanowi to oczywisty dowód wagi, jaka do modelu państwa prawa przywiazywał ustawodawca i wyróżnia polską ustawę zasadnicza spośród innych konstytucji europejskich, z których żadna tego nie czyni (być może nie bez powodu). $Z$ drugiej jednak strony idea ta, w specjalistycznej, prawniczej i politologicznej, literaturze polskiej jest bardzo słabo obudowana teoretycznie. Brakuje szerszych analiz tej koncepcji, wyróżnienia jej aspektów, gruntownych opisów tradycji, z których się wywodzi, historycznych kontekstów jej powstania, teorii, w których idea państwa prawa została przedstawiona, wyjaśniona i uzasadniona. Rozdźwięk między znaczeniem przypisywanym tej idei a niedostatkami wiedzy na jej temat może dziwić.

\footnotetext{
1 Z zagadnieniem podstaw społecznych ustroju konstytucyjnego, państwowoprawnego, wiąże się oczywiście także idea społeczeństwa obywatelskiego i jego relacji do państwa, ale tę bardzo szeroka problematykę traktuje jako odrębną i nie będę jej tutaj poruszał.
} 
„Dobre” społeczeństwo i państwo prawa...

Zarazem jednak idea ta jest wciąż przywoływana i ewokowana. Niezliczone odwołania do niej można znaleźć w piśmiennictwie naukowym $z$ dziedziny historii, socjologii, politologii, w dokumentach instancji władzy państwowej, w publicystyce politycznej, w debatach publicznych. Kontekst tych odwołań jest zawsze jednoznacznie pozytywny, idea państwa prawa znajduje się na piedestale, jest podawana jako wzorzec zespołu zasadniczych rozwiąań ustrojowych, jako rzeczywisty ideał. Warto jednak zauważyć, że fakt ten - przy wyraźnym niedostatku wspomnianych opracowań i studiów na jej temat - może budzić obawę, iż idea ta jest pojmowana w sposób bezkrytyczny, bezrefleksyjny, naśladowczy, bez wykazania jej słabych miejsc czy polemicznych wobec niej stanowisk.

Oczywistość, jaka dziś towarzyszy idei państwa prawa funkcjonującej $\mathrm{w}$ debacie publicznej i piśmiennictwie naukowym, nie jest na pewno czymś przypadkowym ani bezzasadnym; być może stanowi wynik jednomyślności w kwestii relacji państwa do prawa, zasady prymatu konstytucji w państwie, ale przede wszystkim jest na pewno szczególnym signum temporis, nad którym warto byłoby głębiej się zastanowić. Być może bowiem oczywistość, która świadomość współczesna łączy $z$ idea państwa prawa wynika stąd, że ideowe, substancjalne, religijne lub metafizyczne legitymizowanie władzy uważa się już za niemożliwe i niepotrzebne. Pojawiło się ono w szczególnym momencie historycznym, u progu nowożytności; jeszcze w średniowiecznym feudalizmie nie było ani miejsca, ani potrzeby na taka formę legitymizacji. Pojawiła się ona wraz z powstaniem władzy państwowej, która była silną, skoncentrowaną i scentralizowana władzą suwerenna. Dziś coraz częściej mówi się o tym, że ta postać władzy nie ma już racji bytu, że zastąpiły ją różne instancje zarządu (government), instancje spełniajace $\mathrm{w}$ interesie publicznym rozmaite funkcje. Zanikła władza wymagająca legitymizacji, pozostała zaś władza, która musi być przede wszystkim, jeśli nie wyłącznie, legalna. Być może więc źródłem wspomnianej oczywistości jest ten właśnie historyczny proces przechodzenia od państwa władzy do państwa prawa, od legitymizacji do legalizacji? 
Idea państwa prawa, tak powszechnie przywoływana, niemal zawsze jest sprowadzana do jednej zasadniczej kwestii, a mianowicie występuje jako synonim rządów prawa, poddania władzy prawu, jako synonim zasady nadrzędnego znaczenia i rangi konstytucji $\mathrm{w}$ ustroju państwowym. Państwo prawa w swej czystej postaci, może najbardziej ideowej właśnie, to państwo, w którym prawo nie stanowi tylko ram i barier dla państwa i działania władzy, ale państwo, które $z$ prawa bierze swój początek i podstawę.

Pytanie o ideę rządów państwa prawa wydaje się razić racjonalność swą ogólnością i stawiającemu to pytanie można zarzucić, że sprowadzając doń zagadnienia państwa prawa, czyni rozważania bezprzedmiotowymi, bo „rzady prawa” to sformułowanie nieokreślone i niepełne. W odpowiedzi na ten zarzut trzeba stwierdzić, po pierwsze, że choć koncepcja państwa prawa zawiera wiele szczegółowych elementów (między innymi istnienie konstytucji, podział władzy, niezależność sądów, legalność działania administracji, ochrona prawna wobec decyzji władzy, prawo apelacji), to jednak jej istota jest właśnie uznanie prawa za szczególny środek i miarę kształtowania ustroju państwowego, uznanie norm prawnych za mające moc kształtowania stosunków społecznych, moc regulatywną; szczególny autorytet prawa - nomos basileus - ma być źródłem porzadku państwowego. Ta wyjątkowa, nadrzędna pozycja prawa jest dopiero przesłanka wprowadzenia wszystkich szczegółowych rozwiązań konkretyzujących ideę państwa prawa. Nie może więc dziwić fakt, że wspomniana wyżej oczywistość wiążąca się $z$ idea państwa prawa to właśnie oczywistość tego jej zasadniczego rdzenia znaczeniowego: wizji rządów prawa; jest ona dość nieokreślona, ale właśnie dlatego trzeba pytać o jej konkretna zawartość treściowa.

Formuła „rządy prawa” nie skrywa właściwie swego polemicznego charakteru, negatywnego odniesienia; odnosi się mianowicie przecząco do innej wizji państwa - do państwa, w którym rządy sprawują ludzie. Rządy po prostu, to rządy ludzi, jeśli natomiast formułuje 
się zastrzeżenie: „rządy prawa”, to właśnie dlatego, by prawo zastapiło rządy ludzi, aby autorytet prawa zastapił ludzkie zwierzchnictwo. Można to ująć jeszcze inaczej, krócej: władzę ma zastapić prawo. To właśnie sformułowanie naprowadza na istotna kwestię szczególnych założeń tkwiących w idei „rządów prawa”. Po pierwsze, maja to być rządy nie opierające się na przymusie, nieopresywne; ma to być władza, ale właściwie raczej metafora władzy niż władza dosłowna. Jeśli bowiem rządy prawa mają zastapić rządy ludzi, to dlatego, że rzady ludzi (albo władza po prostu, dosłownie rozumiana) łącza się zawsze $z$ przymusem $w$ jakiejś formie, $w$ jakimś sensie, w jakimś stopniu; przymus zaś zniewala, czyni człowieka poddanym, każe przyjąć coś wbrew jego woli, a to przeczy godności człowieka. Rządy prawa to rzady bez przymusu, przynajmniej w jakiejś sferze życia publicznego, sferze istotnej dla porządku państwa. Albo też sa to rządy, w których przymus występuje ograniczony radykalnie, do całkowitego minimum, i jest traktowany nie jako zrozumiały, naturalny modus władzy, przymiot władzy majacej autorytet, przejaw jej mocy, ale tylko jako dosłowna, fizyczna, choć legalna przemoc, stosowana w wyjątkowych przypadkach - deliktach. Po drugie, rzady prawa sa $\mathrm{w}$ tej koncepcji synonimem dobrowolnego poddania się ludzi normom, przyjętym zasadom, poddania się ze względu na ich treść, ich słuszność, racjonalność; to ważność norm nadaje im range nadrzędna, regulujaca, a nie fakt ich ustanowienia przez władzę. Maja to być rządy prawa, ale nie prawa narzuconego, wymuszonego, ograniczającego wolność, grożącego karami i superprokuratorem, owszem, prawa, ale takiego, które nie jest żadna ukryta postacią zwierzchniej władzy, nie jest inna, obca, nadrzędna instancja, nie jest jarzmem. Chodzi więc o prawo, które jest dziełem własnym ludzi mu poddanych, przejawem ich woli i autonomii.

Uważam, że te właśnie dwa momenty - rządy bez przymusu oraz rządy norm dobrowolnie uznanych - stanowia najbardziej szczególne rysy znaczeniowe idei „rządów prawa”, a w konsekwencji koncepcji państwa prawa. 
Dochodzenie do milcząco przyjmowanych założeń tkwiących w idei Rechtsstaat, a dotyczacych człowieka i społeczeństwa, nie jest jednak bynajmniej badaniem, w jakim stopniu idea ta "pasuje” do rzeczywistości, jak dalece jest realistyczna. Jest to raczej szukanie jej racji, dochodzenie do podstawy, na której budowana jest cała koncepcja państwowoprawna, aby dopiero potem starać się, być może, ocenić jej „realizm”. Każda modelowa postać, teoria porządku politycznego, przynajmniej w czasach nowożytnych, czerpie przecież swe racje $z$ rozumienia kondycji ludzkiej lub wyobrażenia o życiu społecznym (w naturze lub w historii), opiera się na tej podstawie, wyprowadza $z$ niej konsekwencje, poddaje ja ocenie, odnosi się do niej afirmujacco lub krytycznie, ale zawsze ze względu na nia i dla niej projektuje porzadek polityczny. Jeżeli takich podstaw nie ma, jeśli nie można ich znaleźć, to czyni to teorię zasadniczo niepełna i w istotny sposób ułomną. Może to paradoks, ale chyba zwłaszcza idea państwa prawa skłania do pytania o tę podstawę antropologiczna lub społeczna, choć może bardziej niż filozofów jest ona idea spekulatywnie myślących mężów stanu, polityków, prawników, których poglądy, jak można by sądzić, ugruntowane są na bardziej „empirycznym” oglądzie, sa związane bardziej z bezpośrednio obserwowalna rzeczywistościa społeczna.

Trzeba więc $\mathrm{w}$ końcu zapytać wprost: jaki jest obraz społeczeństwa w państwie prawa, jakie jest społeczeństwo, do którego „pasuja”" rządy prawa, jaką wizję życia społecznego zakłada ta idea? Odpowiedź zdaje się wręcz narzucać, choć nie jest przez to mniej zdumiewajaca: musi to być obraz, w którym przejawia się wyraźnie optymizm antropologiczny, musi to być obraz społeczeństwa „dobrego". Co to znaczy? Może to oznaczać wiele rzeczy, na przykład społeczeństwo racjonalne, w jakiejś głębokiej swojej strukturze jednomyślne, społeczeństwo, w którym praktykowane są zgodnie pewne zasady, być może banalne, proste, ale wspólne; społeczeństwo, w którym zgoda dominuje nad sporami, ład nad 
bezładem, jedność nad konfliktami, integracja nad podziałami... Dlaczego taki właśnie obraz, obraz społeczeństwa „dobrego”, miałaby zakładać ta idea? Dlatego, że skoro ma ono bez przymusu i dobrowolnie poddając się prawu, zachować ład, stabilność, spójność, to tylko $z$ tego powodu, że w zasadzie ono takie jest, że te cechy tkwia w jego „naturze”, w naturze tego - być może przez to wyjatkowego - społeczeństwa. I dalej: skoro budowane w nim państwo i władza państwowa maja być $z$ góry określone prawem, to tylko takim prawem, które nie jest wytworem władzy, ale dane jest skądiną - żyje, jakoś działa w samym społeczeństwie, tkwi $\mathrm{w}$ nim w postaci świadomości prawnej, poczucia praworządności lub w innej postaci, w której jest przynajmniej potencjalna forma faktycznie sformułowanego potem prawa ${ }^{2}$.

Polemiczny charakter rozważanej idei potwierdza rozpoznanie "dobrego" społeczeństwa jako jej podstawy: państwo prawa jest przeciwieństwem państwa władzy; skoro więc państwo władzy - jego racja i potrzeba - wynika $z$ przekonania, że społeczeństwo jest bezładne, bezrządne, anomiczne, jest sfera dezintegracji oraz permanentnego, jawnego lub ukrytego konfliktu, to można wnosić, iż przeciwstawna koncepcja państwa prawa opiera się na założeniu, że społeczeństwo „normalnie” jest zgodne i stabilne. Czy przekonanie o „złym” albo „dobrym” społeczeństwie mogłaby potwierdzić jakaś wiedza socjologiczna, jakiś opis socjologiczny, w szczególny sposób skonstruowany metodologicznie? Jeśli nie, to co $z$ tego wynika dla nauki, dla polityki - to kolejne istotne pytania. Warto przy tym od razu zauważyć, że żaden opis so-

\footnotetext{
2 Oczywiście, w związku z tym pojawia się wiele zasadniczych kwestii i pytań, między innymi: (1) czy dotyczy to każdego społeczeństwa, czy tylko niektórych i dlaczego właśnie tych; (2) czy taka przedpolityczna podstawa moralna może trwać niewyczerpana, czy też musi być kultywowana i wzmacniana działaniami państwa; (3) czy ten charakter społeczeństwa, stanowiący podstawę ustroju, wytrzyma próbę czasu, czy wytrzyma w zderzeniu $z$ wyzwaniami, $z$ jakimi zbiorowość ta musi się zmierzyć, czy umożliwi na przykład podjęcie polityki koniecznej w obliczu jakichś szczególnych wydarzeń; (4) czy ten fundament etyczny daje sie opisać jako zbiór konkretnych, świadomie funkcjonujących w danej zbiorowości zasad, czy też może występować dyskretnie, utajony, jako potencja możliwa w jakiejś chwili do aktualizacji; (5) czy treści te mają zostać sformułowane w konstytucji, w prawie, czy też wręcz nie należy tego czynić, gdyż mają inne, jeszcze bardziej podstawowe znaczenie i stanowią dla społeczeństwa „duchowy" kontekst funkcjonowania prawa.
} 
cjologiczny nie jest opisem natury społeczeństwa; taki dodatek - „opis natury” - może pochodzić od filozofa, a nie od socjologa; $z$ drugiej strony może jednak nie bez powodu mówi się o tym, co filozoficzne $w$ wiedzy naukowej, może więc $z$ dorobku socjologii można spekulatywnie wydobyć taki opis.

Taki wynik „archeologicznych” poszukiwań podstaw społecznych państwa prawa może się wydawać jaskrawo fałszywy; wizję „dobrego” społeczeństwa można wyśmiać, wyszydzić, nazwać czysta utopią i wyrazem naiwności, wyrazem czyichś idealistycznych złudzeń. Mimo jednak tych zastrzeżeń należy zwrócić uwagę, że przecież pesymizm antropologiczny bynajmniej nie może być z góry uznany za prawdziwszy, bliższy rzeczywistości życia społecznego. I dodać koniecznie trzeba to zwłaszcza, że chodzi tu najpierw nie o sam rzeczywisty obraz społeczeństwa, nie o to, jakim ono realnie jest, ale o to, jaki jego obraz, jaka świadomość społeczna zakłada idea państwa prawa. A wreszcie wszystkim „pozbawionym złudzeń”, „gorzkim realistom” należy przypomnieć, że społeczeństwa sa jednak bardzo różne, a wśród nich znajdują się też i takie, które sa „szczęśliwsze”, choć może trudno wytłumaczyć dlaczego - społeczeństwa, w których charakterze leży praworządność, nazywana tam common law, albo etyczność, nazywana habits of heart. Warto w tym miejscu przytoczyć wypowiedź, której autorem jest Seymour Martin Lipset: „Zrodzone $z$ rewolucji Stany Zjednoczone sa krajem zorganizowanym wokół ideologii, w której skład wchodzi zbiór dogmatów o charakterze dobrego społeczeństwa [...]. Jak powiedział G.K. Chesterton: Amerykanie sa jedynym narodem na świecie, który powstał dzięki przekonaniom. $Z$ dogmatyczna, a nawet teologiczna jasnościa przekonania te zostały wyłożone w Deklaracji Niepodległości”3.

Można jednak wobec postawionej tu tezy „optymizmu antropologicznego" podnieść i ten zarzut, iż o społeczeństwie tworzacym ustrój państwa prawa mówi się dziś z powaga i z przekonaniem,

3 S.M. Lipset: American Exceptionalism. A Double Edged Sword, W.W. Norton \& Co. Inc., New York - London 1996, s. 31 
że stanowi ono zbiorowość ludzi pojmowanych jako jednostki, będace podmiotami naturalnej ich wolności oraz godności, że więc standard ustrojowy dzisiejszego państwa, państwa prawa, zakłada nie tyle społeczeństwo „dobre”, ile raczej społeczeństwo wolne, określone przede wszystkim przez prawa jednostki, naturalne, podstawowe. $\mathrm{W}$ tym kontekście nawet jakakolwiek wzmianka o podstawach etycznych życia zbiorowego byłaby całkowicie nieuzasadniona i mogłaby stanowić powód do krytycznych uwag, że oto $\mathrm{w}$ ten sposób ogranicza się właśnie wolność i naturalny w społeczeństwie pluralizm.

Trudno się oczywiście nie zgodzić z tym, że współczesne państwo - świeckie, pluralistyczne, państwo prawa i dobrobytu - jest „wolnościowe", jest zbudowane w wolności i w celu jej zabezpieczenia, zabezpieczenia praw jednostki. Ale to, mimo wszystko, nie neguje konieczności istnienia podstaw etycznych wspólnego życia; przeciwnie, przestrzeń życia określona tylko przez wolność byłaby w zasadniczy sposób obarczona dwuznacznością. Wolność bowiem, jaka - zwłaszcza wedle pewnych koncepcji - zakłada współczesne sekularne, modernistyczne (albo już postmodernistyczne) państwo, nie jest odniesiona do niczego poza soba, nie jest niczym regulowana, albowiem, jak się powiada, sama „wolność konstytuuje wszystko". $Z$ równym przekonaniem można jednak stwierdzić, że sama „wolność nie konstytuuje niczego"4; sama wolność jest zniesieniem ograniczeń, barier, brama stojąca otworem; prowadzi przez nia droga zarówno ku „liberalizmowi strachu”, jak i ku „liberalizmowi odwagi"' Te dwie logiczne, wyrozumowane możliwości wykorzystania wolności nie moga pozostawić społeczeństwa w stanie rozchwiania, muszą być w praktyce, w życiu na co dzień, czymś zabezpieczone; niepewność w nich tkwiąca musi zostać usunięta - tego chyba wręcz wymaga „psychika” społeczeństwa. Wprawdzie często mówi się o zaufaniu dla samoregulujacych sił wolności,

\footnotetext{
4 Por. E.W. Böckenförde: Erfolge und Grenzen der Aufklarung. Acht Thesen, „Universitas” 1995, nr 590.

5 Por. M. Król: Liberalizm strachu czy liberalizm odwagi, Społeczny Instytut Wydawniczy Znak, Kraków 1996.
} 
ale ufność $\mathrm{w}$ działanie tych sił musi jednak być podbudowana jeszcze przekonaniem, wiara $\mathrm{w}$ to, że wolność zostanie wykorzystana „dla dobra”, „na pożytek”. Wolne społeczeństwo - aby żyć w pokoju, zachować ład, rozwijać się - musi być także w jakiś elementarny sposób zgodne, przynajmniej w swych podstawowych poglądach na życie, jego wartość, cele. Wolność i jedność musza się w jakiś sposób równoważyć.

Również niewystarczające wydaje się rozumienie państwa prawa jedynie jako tworzącego system polityczny zabezpieczający przed zniewoleniem, a więc odnajdywanie jego podstaw tylko w społecznej postawie obronnej przed uzurpacjami władzy. Aczkolwiek jest to na pewno element uzasadniający ideę państwa poddanego prawu, to jednak samo takie negatywne odniesienie - minimalistyczne i relatywizujace - nie stwarza mocnych przesłanek jego uznania, a nadto zakłada znowu wolność, która rzekomo konstytuuje wszystko ${ }^{6}$.

Jaki jest związek między etycznościa, wspólnotowym wymiarem życia społeczeństwa a prawem, które w państwie prawa stanowi instancję sprawująca rządy? Odpowiedź na to pytanie jest oczywiście trudna, uważam jednak, że można tu wskazać na trzy relacje. Po pierwsze, postawy etyczne określajace charakter społeczeństwa moga stanowić kontekst, sprzyjające otoczenie, dzięki któremu działające $\mathrm{w}$ jego obrębie prawo państwowe zyska na znaczeniu, na sile normatywnej, oraz będzie skuteczniej wpływać na zachowania i postawy obywateli. Po drugie, prawo ustanowione oraz etyczny wymiar życia społeczeństwa - wyrażający się we wspólnie uznawanych, choć niekoniecznie zwerbalizowanych, świadomie pojmowanych, uzasadnionych postawach, przekonaniach, obyczajach, wzorcach, normach, hierarchiach - będą się uzupełniać, odwoływać do siebie i w ten sposób wzajemnie wzmacniać, utrwalać jako miarodajne punkty odniesienia. Po trzecie, prawo państwowe można

\footnotetext{
6 Wśród teorii politycznych i społecznych znajduja się też i takie, które etycznego wymiaru życia społeczeństwa nie uznaja za konieczny; jest on dla nich wręcz zbędny. Głosić taka teze miałaby na przykład teoria społeczna Adama Smitha. Podejmowanie jednak dyskusji z taka, niepełna chyba, jej interpretacją wykracza poza ramy niniejszego tekstu.
} 
uważać za aktualizację istniejących potencji zgody, jedności, wspólnoty, potencji, które tkwią w społeczeństwie, mają wiele różnych źródeł oraz moga się ujawniać $\mathrm{w}$ różnych okolicznościach życia i pod ich wpływem. Gdy znajda swój wyraz, konkretny i realny kształt jako treści, normy prawa same zyskają większą realność.

W podjętych tu rozważaniach starałem się dotąd wskazać na założenia, jakie idea rządów prawa czyni w odniesieniu do społeczeństwa, w którym państwo prawa powstaje i dla którego funkcjonuje. Istnieje jednak poza ta jeszcze inna, kardynalna w tym kontekście kwestia, a mianowicie kwestia już nie jego podstawy, ale rozumienia samego prawa, prawa mającego nadawać całościowe ramy państwu i jego władzy. Można powiedzieć, że wyrażenie „rządy prawa" ma charakter metaforyczny, ale zwolennicy tej koncepcji chca je traktować jak najbardziej dosłownie; istotnie postuluja, by odebrać władzę jednostkom, ludziom, a powierzyć ja instancjom meta, bezosobowym: ustawom, procedurom, normom („prawo mówi”, „przepis prawa stwierdza”, „konstytucja rozstrzyga”, „ustawa głosi”, „ustawodawca postanowił” itd.). Podejrzliwość, brak zaufania do ludzi sprawujacych urzędy, majacych w rękach ster władzy, zastapiona jest tu wiara w funkcjonowanie prawa jako „systemu”. Dlatego formuła „rządy prawa” wydaje się wyrazem tak zwanych pobożnych życzeń, swego rodzaju utopia. Jak ja obronić przed tym zarzutem, jak rozumieć rządzące prawo, by można było te ideę uznać za realistyczna propozycję, by ją uprawdopodobnić? Trzeba przydać prawu bliższe określenie dotyczące jego rodzaju i sposobu jego funkcjonowania; dopiero to może uczynić tę koncepcję celowa i wykonalną.

Jeśli prawo ma sprawować rządy, jeśli maja istnieć rządy prawa, a nie władzy, to musi to być prawo:

- które każdy obywatel może współkształtować; będące wyrazem woli tych, którzy mu podlegaja, najlepiej ustanowione bez- 
pośrednio przez nich, a nie przez skonstruowana już i pośrednio demokratyczną władzę;

- na równi obowiązujące wszystkich oraz przez wszystkich przestrzegane, działajace w sposób skuteczny i pewny;

- nie dla idei, ale dla społeczeństwa, dostosowane do tych realiów, standardów, powszechnych praktyk, które w nim występuja, prawo nie wnoszace zbytnich rygorów, nie stawiajace nadmiernych wymagań, nie stosujące obcych miar;

- odrębne, wyróżnione, właśnie jako to prawo, które ma rzadzić, które dotyczy ustroju, polityki - prawo konstytucyjne, różne i oddzielone od innych gałęzi prawa, których system zwieńcza, oddzielone od tych gałęzi prawa, które jednoznacznie zakładaja władzę, władzę stanowiąca i egzekwująca;

- możliwe do poddania go rewizji, zmianie, wskutek czego, choć będzie miało charakter tymczasowy, będzie jednak też stale pojmowane jako środek, narzędzie służące kształtowaniu życia społecznego;

- projektujące „państwo małe”, pozostawiające obywatelowi duże pole do własnej samorealizacji, szeroki zakres swobodnego działania, a więc prawo wzniesione na fundamencie praw jednostki, praw człowieka;

- „spolegliwe”, majace charakter koncyliacyjny, pragmatyczny i rozsadkowy; musi ono zakładać jednostkę jako podmiot świadomości prawnej, jako jednostkę praworządną, musi wzmacniać „portret własny” obywateli jako racjonalnych i światlych;

- pojmowane normatywistycznie, wzmacniajace przekonanie, że odnosi się do życia społecznego, które jest „normalne”, typowe, przewidywalne, swojskie;

- pozostawiajace jednak jakieś miejsce dla uregulowanej, prowadzonej fair walki, rywalizacji politycznej, aby stanowiła ona „wentyl bezpieczeństwa” dla przejawianych namiętności politycznych, dla umiarkowanego konfliktu interesów;

- zabezpieczajace działanie samego prawa, to znaczy zwłaszcza stwarzające różne instancje dające możliwość debatowania i poko- 
jowego rozstrzygania sporów dotyczących prawa, sporów powstających mimo zasadniczej zgody w społeczeństwie;

- przewidujace ochronę własnego porzadku przed jego wrogami traktowanymi jak „ekstremiści”, a więc ludzie kontestujący same zasady życia społeczeństwa i ustroju, grożący jego zniszczeniem;

- last but not least: musi to być prawo będace czytelnym komunikatem, przekazem społecznym, czyli jasno napisane, zwięzłe, rzeczowe, spójne, dobitnie sformułowane, mające wyraźnego adresata.

Wśród wymienionych wyżej wymagań, jakie koncepcja materialnego państwa prawa stawia przed prawem, wymagań określających jego charakter oraz rolę $\mathrm{w}$ państwie i wobec społeczeństwa, istotne sa te (choć na pewno nie tylko), które podkreślają demokratyczny sposób stanowienia prawa oraz fakt, że wznosi się ono na fundamencie praw jednostki. Warto jednak zwrócić uwagę na pewne możliwe konsekwencje, które wynikaja $z$ takiego sposobu nadania prawu wymiaru aksjologicznego (mającego różnić materialna koncepcję państwa prawa od koncepcji formalnej), a mianowicie: skoro uznane zostaje prawo, o ile jest ono ustanowione przez demos, o ile jest jego wytworem, to fakt, że obywatele tworza prawo, zmieniaja, uzupełniaja, wpłynie bezpośrednio na jego znaczenie, pozycje, tym razem jednak deprecjonujacco. Sprawi bowiem, że obywatele będą traktować prawo jako coś dla siebie, poddane sobie, istniejace ze względu na nich; porządek prawny będzie porządkiem wciąz prowizorycznym, niestałym. W ten sposób prawo straci na znaczeniu, nie będzie czymś, czemu człowiek ma się podporządkować, ale czymś, co jest od niego zależne i co traktuje instrumentalnie. $Z$ tych samych powodów będzie to prawo funkcjonujace stale pod presja działania politycznego, pod naciskiem wywieranym na nie przez reprezentantów demosu, czyli przedstawicieli partii politycznych. Patrzac $z$ tej perspektywy, widać, że daremne sa stale powtarzane utyskiwania na napięcie istniejące między prawem a polityka, na stała ingerencję polityki $\mathrm{w}$ sferę prawa. Napięcie to i ingerowanie jest nieuchronne; opozycja poli- 
tyka-prawo jest wpisana do tej koncepcji państwa, należy do istoty materialnego państwa prawa.

Ponadto skoro uznaje się w tej koncepcji fundamentalne znaczenie praw człowieka, to (1) istotnie, one staja sie fundamentem, ale w związku $z$ tym cała, wzniesiona na nich część porząd$\mathrm{ku}$ prawa jest, $\mathrm{w}$ porównaniu $\mathrm{z}$ nimi - a one stanowia tu miare - ruchoma, relatywna, niestała i jak gdyby wtórna, może być nieustannie przekształcana, zmieniana, rewidowana, uzupełniana; (2) skoro podstawa sa prawa człowieka i skoro to jest podstawa niewzruszona, to na tym tle całe pozostałe prawo, nadbudowane nad nimi, jawi się jako prawo dla ...jednostki, prawo jej służebne, jej podporzadkowane; to prawo jest wtedy poddane jednostce, a nie jednostka jemu.

Deprecjacja prawa będzie tym silniejsza, im słabsza będzie etyczność społeczeństwa w którym prawo to działa.

Można na koniec zapytać, jaki praktyczny wniosek płynie $z$ przedstawionych tu rozważań? Jakie pytania stawiają one przed projektodawcami konstytucji państwa prawa? Sądzę, że na ich tle pojawia się jedno zasadnicze, choć trudne pytanie: czy społeczeństwo polskie jest społeczeństwem „dobrym”. Jeśli tak, to w jakim sensie, w jakim stopniu, na czym polega jego etyczność? Czy stanowi element trwały? Jakie ma perspektywy, poddana dynamice rozwoju społecznego? A może etyczność ta jest wątła, nikła, porwana? Czy można by się temu dziwić po czterdziestu latach, w czasie których próbowano czynić ze społeczeństwa „miazgę", starano się je wykorzenić? Sa to pytania, na które niełatwo znaleźć pełna odpowiedź, ale które "ustrojodawca" musi sobie postawić, aby wiedzieć, jaki ma tworzyć model ustrojowy, jaką rolę ma wyznaczyć państwu, aby wiedzieć, jakie sa niebezpieczeństwa i zagrożenia dla polskiej racji stanu albo może jakie sa gwarancje pokoju, ładu, rozwoju w polskim społeczeństwie - jakie one są albo raczej $z$ czym się wiążą. 